\begin{tabular}{|l|c|c|c|c|}
\hline $\begin{array}{l}\text { Cuadernos de Investigación Geográfica } \\
\text { Geographical Research Letters }\end{array}$ & 2019 & N $^{\circ} 45(1)$ & pp. 123-141 & eISSN 1697-9540 \\
\hline
\end{tabular}

\title{
WINNERS AND LOSERS OF LANDSCAPE CHANGES OVER THE LAST SIXTY YEARS IN ONE OF THE OLDEST AND SOUTHERNMOST NATIONAL PARKS OF THE EUROPEAN ALPINE REGION: ORDESA AND MONTE PERDIDO
}

\author{
M.B. GARCÍA*, P. ERREA, D. GÓMEZ, M. PIZARRO \\ Instituto Pirenaico de Ecología, Consejo Superior de Investigaciones Científicas (IPE-CSIC) \\ P. O. Box 13034, 50080 Zaragoza, Spain.
}

\begin{abstract}
Traditional land-use decline in Mediterranean mountains is translating into extensive forest recovery and the loose of "cultural landscapes". In this context, the management of semi-natural ecosystems plays a fundamental role for the future preservation of species and processes, particularly in protected areas, and managers need rigorous information for an integrative interpretation of the long-term and complex effects of land cover replacement. Here we analyze changes in the land cover structure of the Ordesa and Monte Perdido National Park and its peripheral protection zone, by comparing 7 types of patches from aerial photographs taken in 1956 and 2015. Then, we discuss how this process affected landscape diversity and two kinds of potential vulnerable plants. We found higher changes in the unprotected than protected areas, concentrated below the treeline in both cases, as a result of forest densification and strong reduction of anthropic and unvegetated areas. Total edge of patches decreased, as well as the number of patches, whereas mean patch size increased, indicating that patches merged and ecotones reduced. Shannon diversity index of the landscape decreased too, confirming a simplification of the system. Most Pyrenean endemic plants and threatened ones occur either on stable grasslands over the treeline, "winner" forests, or as rocky specialists irrespective of the land cover class. Therefore, past landscape changes do not seem to have affected them negatively, and forest expansion could also benefit several plants and treedominated communities at the south limit of distribution (Abies alba, Fagus sylvatica, Pinus uncinata). Landscape simplification, however, translates into plant diversity reduction too, which could be slowed down by creating or keeping small open patches inside matrices of forest. Maximization of plant diversity would require in this case some human perturbation, but at lower intensity than in the far past, in order to preserve large stands of old forests too.
\end{abstract}


Ganadores y perdedores de los cambios paisajísticos ocurridos durante los últimos 60 años en uno de los Parques Nacionales más antiguos y meridionales de la región Alpina Europea: Ordesa y Monte Perdido

RESUMEN. El declive de los usos tradicionales en las montañas mediterráneas se está traduciendo en una recuperación del bosque y la pérdida de "paisajes culturales”. En este contexto, la gestión de los ecosistemas semi-naturales, especialmente en espacios protegidos, debe jugar un papel fundamental para la futura preservación de especies y procesos ecológicos, y los gestores requieren información rigurosa para una interpretación integradora de los efectos a largo plazo del reemplazamiento de hábitats. En este estudio analizamos los cambios en la estructura de la ocupación del suelo dentro del Parque Nacional de Ordesa y Monte Perdido y su zona periférica, comparando manchas de 7 tipos de cobertura a partir de fotos aéreas tomadas en 1956 y 2015. Discutimos después los efectos que dichos cambios han tenido en la diversidad del paisaje y en dos grupos de plantas potencialmente vulnerables. Se han producido más cambios en la zona periférica que dentro del parque, en ambos casos casi en su totalidad por debajo del límite del bosque. Dichos cambios son el resultado de una densificación y expansión de bosques, y la fuerte reducción de cultivos y zonas sin vegetación. El borde de las manchas y su número ha decrecido, habiendo aumentado su tamaño medio, lo que indica fusión y la consecuente reducción de ecotonos. La diversidad paisajística también se redujo, lo que confirma una simplificación del sistema. La mayor parte de los endemismos pirenaicos y las plantas amenazadas se localizan en pastos, ambientes forestales, roquedos y otros sustratos rocosos por encima del límite del bosque. Los cambios de paisaje registrados, por tanto, no parecen haberles afectado negativamente, mientras que han podido beneficiar a plantas vinculadas a bosques, situadas en su límite sur de distribución. La simplificación del paisaje, no obstante, tiene como consecuencia una reducción de la diversidad, que podría frenarse con el mantenimiento o la creación de pequeños espacios abiertos dentro de la matriz forestal. El aumento de la diversidad vegetal requiere en este caso fomentar la perturbación, aunque ésta debería mantenerse por debajo de la que existió a principios del siglo XIX para poder preservar también bosques maduros de suficiente tamaño.

Key words: Global change, LTER, Pyrenees, traditional land uses, vulnerable plants.

Palabras clave: Cambio Global, LTER, Pirineos, usos tradicionales, plantas vulnerables.

Received: 20 August 2018

Accepted: 25 October 2018

*Corresponding author: María Begoña García, Instituto Pirenaico de Ecología, Consejo Superior de Investigaciones Científicas (IPE-CSIC), Campus de Aula Dei, P.O. Box 13.034, 50080 Zaragoza, Spain. E-mail address: mariab@ipe.csic.es 


\section{Introduction}

Global change effects on natural systems are evident worldwide, and two drivers that often act simultaneously promote the observed changes: climatic warming and land use changes (Mantyka-Pringle et al., 2012; Newbold et al., 2015; Scheffers et al., 2016). The European Environmental Agency has just reported on the high vulnerability and impacts of climatic change (decrease in glacier extent, upward shift of plant and animal species, increasing risk of forest pests...; EEA, 2017), and South European mountains have often been nominated among the areas that will suffer the highest impact (Thuiller et al., 2005; LópezMoreno et al., 2008; Engler et al., 2011). Likewise, land-use changes have been suggested as the global change driver with the highest impact on biodiversity (Sala et al., 2010), and there is ample consensus about recent recolonization by shrubs and trees after the abandonment of farmlands and marginal agricultural areas in mountains (Sitzia et al., 2010). Deep changes in the traditional land uses in rural areas of South Europe due to socio-economic reasons have broken the balance maintained for centuries between natural and human-driven patches, threatening in this way the future of cultural landscapes (García-Ruiz and Lasanta, 2018).

In a global change scenario of rapid changes produced by the overexploitation of natural resources (the Anthropocene, Corlett, 2015), and rural abandonment, mountains are also interesting case studies because they often include protected areas due to the high amount or singularity of the geo-biodiversity they shelter, and their role for the preservation of such values. They offer vertical environmental gradients for life, concentrating contrasted conditions across large areas at farther latitudes. In these territories, changes of landscape structure will have, therefore, important consequences on plant and animal diversity associated to different habitats. Natural and semi-natural European grasslands, for example, are among the world's record communities for vascular plant species richness (Wilson et al., 2012), and pollinators and herbivores have been found to respond to management intensity and plant diversity (Hudewenz et al., 2012). Unfortunately there is little information of the consequences of shifts in the spatial attributes on biodiversity (Sitzia et al., 2010; Wielgolaski, 2017), and both positive and negative effects of landscape change have been reported depending on the biological group, the kind of ecosystem affected, and the management treatment (see for example Falcucci et al., 2007; Bonari et al., 2017). Thus, although protected mountain areas do not escape from the effects of warming, protection should translate somehow into divergent consequences for biodiversity compared to unprotected areas.

Semi-natural ecosystems typical of Mediterranean mountains are shifting, and managers require rigorous information to take actions in order to preserve both biological values and cultural landscapes. Our goal in this study is to describe the dynamics over the last 60 years of the land cover of a currently highly protected area with no human perturbations beyond traditional livestock grazing: the Ordesa and Monte Perdido National Park, and compare it with the surrounding area, where a higher human influence persists. Then we will discuss how those changes would affect overall plant diversity and its most vulnerable elements. Recent analyses carried out with remote sensing for a shorter and more recent period in an area that includes our study site showed that there has been a recovery of natural vegetation (Gartzia et al., 2014; Martínez-Vega et al., 2017). In this study we quantified the extension of changes of land cover classes from aerial 
pictures taken in 1956 and 2015, both in the protected and peripheral area, and above and below the treeline, and compared past-present indexes of spatial metrics (patch number, occupancy, landscape diversity). Then, we discuss the effects of landscape change for Pyrenean endemics and threatened vascular plants, by checking their habitat affinities and overlapping their presence on the map of landscape changes. Our hypothesis is that due to protection, the successional dynamics of the National Park has been different than in its peripheral zone, and that vulnerable plants should find there a safer place to persist. This kind of information will contribute to guide the complex management of such valuable space.

\section{Material and Methods}

\subsection{The study area: characteristics and use}

The Ordesa and Monte Perdido National Park (OMPNP) extends over 15.692 ha, although for this study we analyzed 34.805 ha after adding the peripheral protection zone (PPZ). The National Park is located in a very low populated area (less than 4 inhabitants/ $\mathrm{km}^{2}$ ) in the border between Spain and France, and shows an abrupt topography shaped by 4 deep valleys radiating from the highest calcareous summit in Europe. The minimum altitude is located in the southernmost part, $660 \mathrm{~m}$ a.s.l., at the beginning of the narrow canyon of Añisclo. The highest at the Monte Perdido summit, $3355 \mathrm{~m}$ a.s.l. Rainfall ranges from 850 to $2500 \mathrm{~mm} \mathrm{yr}^{-1}$ according to the oldest meteorological station inside the OMPNP (Góriz, $2200 \mathrm{~m}$ a.s.l.). The climatic trend in the Pyrenees has been documented as an increase of $0.25^{\circ} \mathrm{C}$ per decade between 1950 and 2010 (EEA, 2017).

The OMPNP contains about 30 habitats of Community interest (Commission of the European Communities 1992), one tenth of the estimated European flora, and can be considered a crossroad of Mediterranean, Eurosiberian, Alpine and Boreoalpine ecosystems. Forests extend along basal, montane and subalpine belts, and stands of Pinus sylvestris, $P$. uncinata, Abies alba, Fagus sylvatica, Quercus cerrioides and $Q$. ballota are the most common ones, besides mixed riparian vegetation along rivers (Tilia platyphyllos, Fraxinus excelsior...). Around half of the total extension of the Park is dominated by a large variety of both dense and sparse (often rocky) alpine grasslands, and screes, above $1800 \mathrm{~m}$ a.s.l. approximately.

This is one of the oldest National Parks in Europe, since a small fraction of the Ordesa valley got that protection in 1918 (2055 ha). The rest of the current Park was protected in 1982. For easiness, the OMPNP acronym will always refer to the protected area, PPZ to the peripheral protection zone, and ONP-1918 for the historical area. Spanish legislation for National Parks states that "Declaration as National Park is intended to conserve the integrity of its natural values and its landscapes, subject to the social use and enjoyment of all persons [...] while promoting environmental awareness in society, encouraging scientific research and the sustainable development of the populations involved, in line with the maintenance of cultural values, of the intangible heritage and the traditional activities and uses inherent to the space" (https:/www.mapama.gob.es/es/red-parquesnacionales/ley-parques-bilingue_tcm30-61377.pdf). Grazing is the only traditional use 
allowed, whereas hunting and logging are forbidden. The park is currently visited by around 600.000 people per year, highly concentrated in the summer period. Tourism is the main income source in the surrounding area, which has totally changed the economic structure of the territory in the last decades.

There are no inhabitants in the protected area, and just a few small villages are located in the peripheral area. Similar to the Pyrenean range, however, this area has gone through major changes in land organization, and the natural treeline in the OMPNP was lowered below the natural treeline (approx. till $2100 \mathrm{~m}$ a.s.l.) due to centuries of downslope grassland extension to increase the surface for summer livestock grazing (Anonym, 1976). Cultivations (cereal and potatoes crops) were frequent in the last centuries in the bottom of the valleys and even at mid and high slopes, which were replaced around mid1900 by "mesic pastures" for cattle (we will use this term to distinguish them from the alpine grasslands), which created a mosaic of open-forest vegetation (Fig. 1).

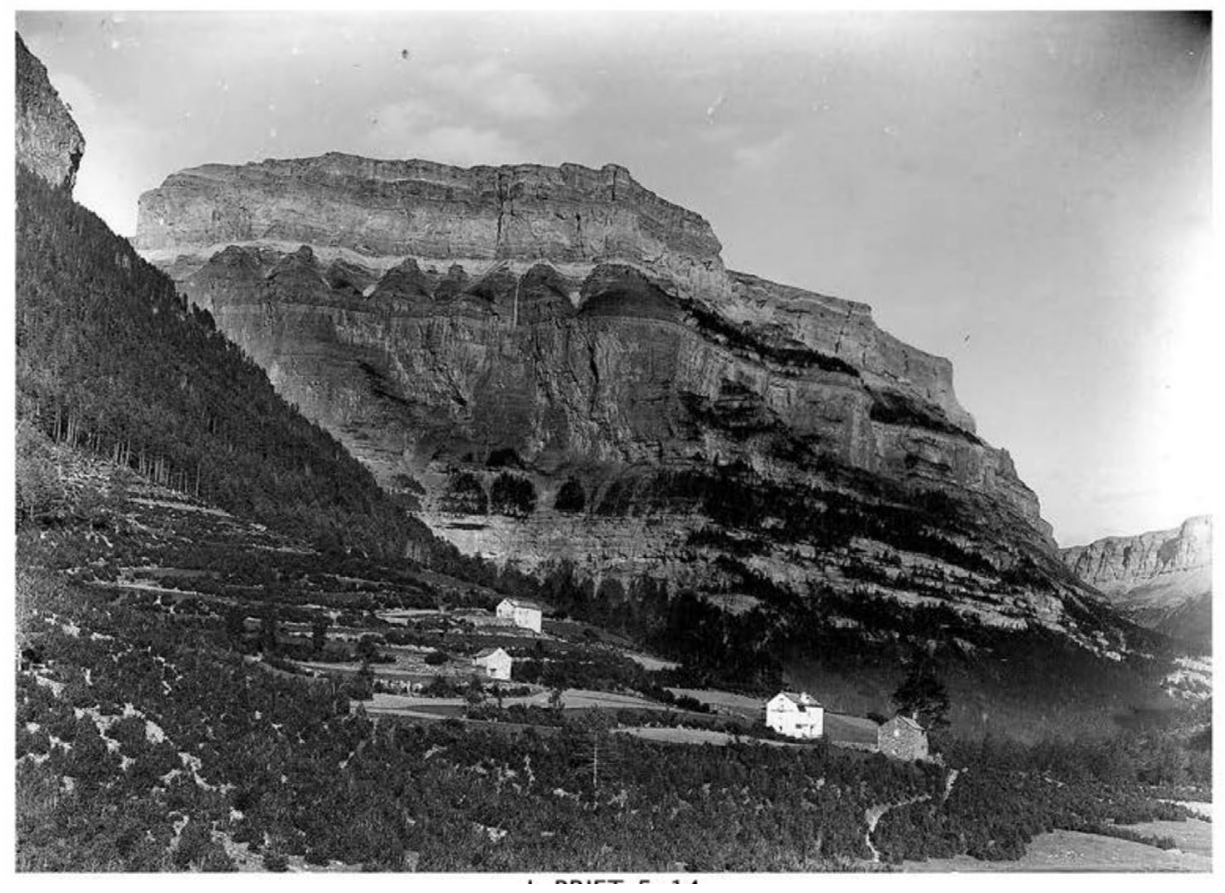

Figure 1. Entrance of the Ordesa Valley at the beginning of the $20^{\text {th }}$ century, some years before the declaration of the Ordesa National Park in 1918. Author: L. Briet.

\subsection{Landscape analysis}

We assessed the land cover change by comparing three sets of aerial pictures: the oldest ones from flights carried out in 1956, and the newest ones in 2015, as well as a set of intermediate pictures taken in 2006. For the old set of pictures, 59 photograms at 
1:33.000 scale were downloaded from the Regional Government (http://sitar.aragon.es), orthorectified with Erdas Imagine (module Leica Photogrammetric Suite) using at least 10 control points per stereoscopic pair, and projected into a Geographic Information System. The 2006 and 2015 pictures were downloaded as digital orthophotos at 1:1.500 scale and $0.5 \mathrm{~m}$ resolution (CNIG 2018). In order to compare the vegetation cover through images and make sure that patch boundaries matched between the oldest and newest sets of images when there was no change, we first manually drew polygons of land cover on aerial pictures taken in 2006 based on maps of the III National Forest inventory (https://www.mapama. gob.es/ es/biodiversidad/servicios/banco-datos-naturaleza/informacion-disponible/ifn3. aspx), because both sources of information were obtained very close in time. Resulting pictures with polygons were overlapped on the old (1956) and new (2015) aerial pictures afterwards, to adapt boundaries to both sets of images with minimum error.

Due to the low resolution (and sometimes poor quality) of the oldest aerial pictures we used a total of seven clearly differentiated land-cover classes: no vegetation (rivers, lakes, bare soil...), anthropic (cultivated fields, meadows...), grassland and rocks above the treeline (distinction was not easy and we preferred to add them together), shrubland, sparse woodland (less than $20 \%$ tree cover), dense woodland (at least $20 \%$ tree cover), and riparian vegetation (narrow belts of mixed trees and shrubs by rivers). The classification of the land cover units was done by the same person in all the three sets of aerial pictures, minimizing in this way differences in patch classification through time.

The overlap of land cover classes between 1956 and 2015 produced a crosstabulated matrix that served to estimate the probability (transition matrix) and magnitude (surface) of changes over the last six decades. We also calculated transition matrices for the 2006-2015 period to see if the change rate was in consonance with the whole 1956-2015 period. Then, some spatial metrics with ecological meaning were calculated at the landscape level for the initial and final study year, to compare rates of change between protected $v s$ unprotected areas: Shannon diversity Index (SDI), number of patches (NumP) and mean patch size (MPS). The later ones were also calculated above and $2100 \mathrm{~m}$ a.s.l., the current timberline (thereafter named also as treeline to facilitate comparisons with previous published information) due to the large differences observed during analysis. Landscape structure and its temporal dynamics were studied using the spatial analysis programs ZonalMetrics (Adamczyk et al., 2017) and Patch-Analyst 5.2 (Rempel et al., 2012) in ArcGIS.

\subsection{Possible effects of landscape change on vulnerable vascular plants}

Unfortunately most plant inventories carried out decades ago were not geolocalized accurately enough as to repeat them and make sure about plant species replacement. Instead, we will explore consequences of landscape changes by focusing on two kinds of a priori vulnerable plants: narrow-distributed (Pyrenean endemics) and threatened. After making a list of native vascular plant species recorded within the limits of the studied area (herbarium vouchers, opportunistic observations and phytosociological inventories; http://floragon.ipe.csic.es), we checked for the validity of each taxon and left out those of no clear taxonomy or doubtful distribution for subsequent analyses (for example 
apomictic taxa of the Alchemilla and Hieracium genus). Then, we extracted Pyrenean endemic plants according to Gómez et al. (in press) and threatened according to regional (Anonym, 1995 and 2005), national (official list and Red list; Anonym, 2011; Moreno, 2008; Bañares et al., 2011) or European catalogues (Habitats Directive; Commission of the European Communities, 1992). Plants of "special interest" (regional Catalogue), and listed in the Annex V of the Habitats Directive were not included because they are not considered "threatened" and do not need protection actions.

Each one of these target plants were associated to at least one of the land cover classes, and also we checked if they occurred on imperturbable rocky habitats irrespective of the altitude and land cover class (for example cliffs within forest stands). Finally we overlapped their records on the map of landscape changes (geolocalization of plant records is often stored at $1 \mathrm{~km}^{2}$ of precision) to infer the probability of affection.

\section{Results}

\subsection{Shifts in the landscape between 1956 and 2015}

The Ordesa and Monte Perdido National Park (OMPNP) is spatially dominated by alpine grasslands and rocky areas, and surrounded by a Peripheral Protection Zone (PPZ) occupied basically by Mediterranean shrublands in the south and alpine grasslands and shrublands in the northwest. Old pictures show that, when originally declared as a protected space one hundred years ago (ONP-1918), the landscape of the National Park looked much less forested than nowadays, and a mix of forests, cultivated fields or pastures, and shrubs dominated the valley (Fig. 1; see many more pictures in Acín, 2000). Nevertheless, $63 \%$ of that surface was already covered with dense forests in 1956.

The land cover of the whole study area has changed $20 \%$ over the last 60 years, mostly concentrated in three areas: south slope of the PPZ, Escuain canyon, and Pineta valley (Figs. 2 and 3). The PPZ experimented more than twofold changes (26.4\%) than the protected one (OMPNP: 11.2\%). Nevertheless, $98 \%$ of those changes (almost 4000 ha.) occurred below $2100 \mathrm{~m}$ a.s.1.

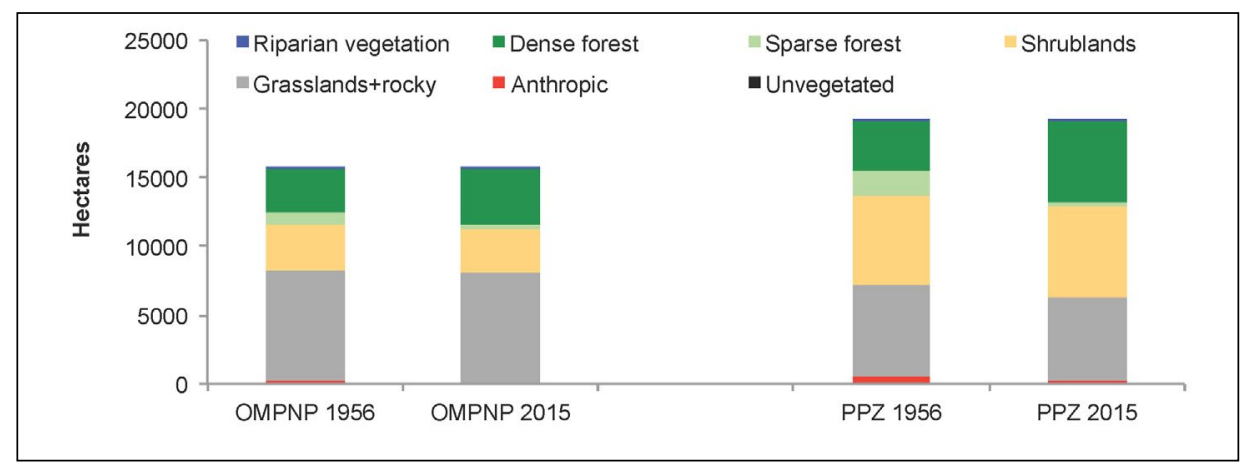

Figure 2. Occupancy area by 7 land cover classes in the Ordesa and Monte Perdido National Park (OMPNP) and the Peripheral Protection Zone (PPZ) in years 1956 and 2015. 


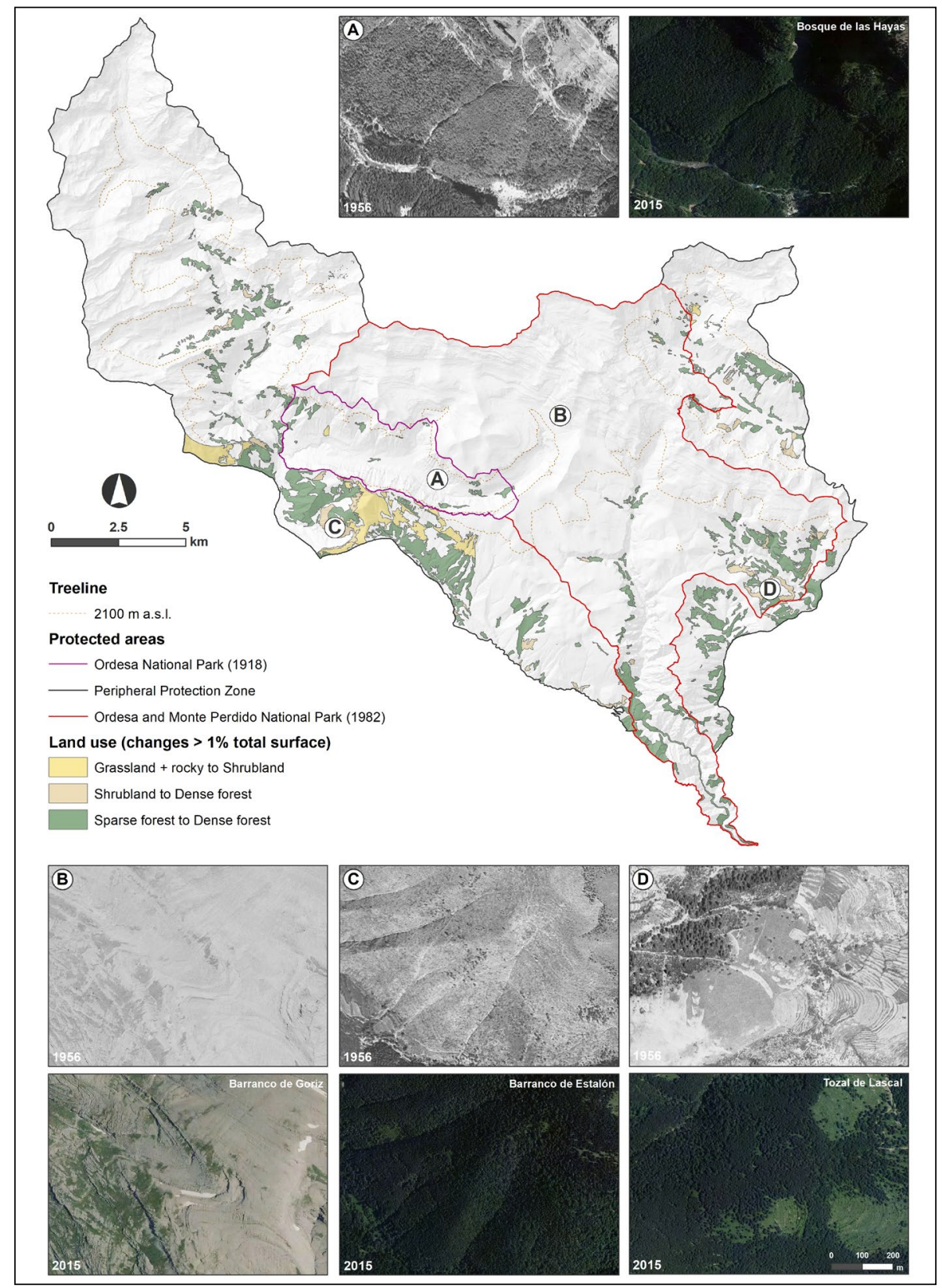

Figure 3. Map of changes in the study area, showing patches of size $>1 \%$ of the total surface and the type of change. Red line: limit of the Ordesa and Monte Perdido National Park as declared in 1982; purple line: limit of the Ordesa National Park as declared in 1918; remaining area: peripheral protection zone. Four pairs of pictures taken in 1956 and 2015 (A, B, C, D) show different intensities of change inside and outside the National Park, and at contrasted altitudes and aspects. 
Table 1. Matrices of changes between 1956-2015, in terms of hectares of occupation by each land cover class (occupancy matrix), and probability of transition among classes (transition matrix), both for the National Park and the peripheral zone. Row and column labels are exactly the same.

\begin{tabular}{|c|c|c|c|c|c|c|c|c|}
\hline \multicolumn{9}{|c|}{ ORDESA AND MONTE PERDIDO NATIONAL PARK } \\
\hline \multirow{2}{*}{\multicolumn{2}{|c|}{ OCCUPANCY MATRIX }} & \multicolumn{7}{|c|}{1956} \\
\hline & & Unveg & Anthropic & \begin{tabular}{|c|} 
Alp \\
grass_rocks
\end{tabular} & Shrubland & $\begin{array}{l}\text { Sparse } \\
\text { forest }\end{array}$ & $\begin{array}{l}\text { Dense } \\
\text { forest }\end{array}$ & $\begin{array}{c}\text { Riparian } \\
\text { veget }\end{array}$ \\
\hline \multirow{7}{*}{ ํี่ำ } & Unvegetated & 52,6 & 0,0 & 0,0 & 0,0 & 0,0 & 0,4 & 0,0 \\
\hline & Anthropic & 0,4 & 27,0 & 0,0 & 0,0 & 0,0 & 0,0 & 0,0 \\
\hline & Alpine grasslands and rocks & 8,4 & 0,0 & 8053,9 & 0,6 & 0,4 & 3,2 & 0,0 \\
\hline & Shrubland & 0,0 & 53,3 & 8,8 & 3113,3 & 14,6 & 0,2 & 0,0 \\
\hline & Sparse forest & 2,6 & 0,0 & 16,5 & 43,4 & 121,5 & 0,8 & 0,0 \\
\hline & Dense forest & 22,1 & 19,2 & 12,7 & 124,7 & 705,2 & 3284,4 & 0,0 \\
\hline & Riparian vegetation & 0,0 & 0,0 & 0,0 & 0,0 & 0,0 & 0,0 & 1,5 \\
\hline \multirow{3}{*}{\multicolumn{2}{|c|}{$\begin{array}{l}\text { TOTAL } 1956 \text { (ha) } \\
\text { 2006-2015 (ha) }\end{array}$}} & 86,02 & 99,54 & 8091,92 & 3282,02 & 841,62 & 3289,04 & 1,53 \\
\hline & & $-33,0$ & $-72,1$ & $-25,3$ & $-91,8$ & $-656,9$ & 879,2 & 0,0 \\
\hline & & Unveg & Anthropic & \begin{tabular}{|c|} 
Alp \\
grass_rocks
\end{tabular} & Shrubland & $\begin{array}{l}\text { Sparse } \\
\text { forest }\end{array}$ & $\begin{array}{l}\text { Dense } \\
\text { forest }\end{array}$ & $\begin{array}{c}\text { Riparian } \\
\text { veget }\end{array}$ \\
\hline \multirow{7}{*}{ 突 } & Unvegetated & 61,1 & 0,0 & 0,0 & 0,0 & 0,0 & 0,0 & 0,0 \\
\hline & Anthropic & 0,4 & 27,1 & 0,0 & 0,0 & 0,0 & 0,0 & 0,0 \\
\hline & Alpine grasslands and rocks & 9,8 & 0,0 & 99,5 & 0,0 & 0,0 & 0,1 & 0,0 \\
\hline & Shrubland & 0,0 & 53,5 & 0,1 & 94,9 & 1,7 & 0,0 & 0,0 \\
\hline & Sparse forest & 3,0 & 0,0 & 0,2 & 1,3 & 14,4 & 0,0 & 0,0 \\
\hline & Dense forest & 25,6 & 19,3 & 0,2 & 3,8 & 83,8 & 99,9 & 0,0 \\
\hline & Riparian vegetation & 0,0 & 0,0 & 0,0 & 0,0 & 0,0 & 0,0 & 100,0 \\
\hline \multicolumn{9}{|c|}{ PERIPHERAL PROTECTION ZONE } \\
\hline \multirow{2}{*}{\multicolumn{2}{|c|}{ TRANSTION MATRIX }} & \multicolumn{7}{|c|}{1956} \\
\hline & & Unveg & Anthropic & $\begin{array}{c}\text { Alp } \\
\text { grass_rocks }\end{array}$ & Shrubland & $\begin{array}{l}\text { Sparse } \\
\text { forest }\end{array}$ & $\begin{array}{l}\text { Dense } \\
\text { forest }\end{array}$ & $\begin{array}{c}\text { Riparian } \\
\text { veget }\end{array}$ \\
\hline \multirow{7}{*}{ ํㅜㅇ } & Unvegetoted & 61,4 & 3,2 & 1,6 & 5,2 & 5,5 & 7,1 & 0,0 \\
\hline & Anthropic & 1,2 & 99,9 & 0,0 & 0,0 & 0,0 & 0,0 & 0,0 \\
\hline & Alpine grasslands and rocks & 2,4 & 0,0 & 6088,5 & 7,1 & 5,8 & 0,2 & 0,0 \\
\hline & Shrubland & 3,0 & 137,1 & 464,9 & 6027,2 & 5,4 & 0,8 & 0,0 \\
\hline & Sparse forest & 0,8 & 13,0 & 60,2 & 28,2 & 132,7 & 0,0 & 0,0 \\
\hline & Dense forest & 68,4 & 103,5 & 149,8 & 281,6 & 1721,6 & 3595,1 & 7,6 \\
\hline & Riparian vegetation & 3,8 & 0,0 & 0,0 & 0,0 & 0,0 & 0,0 & 19,2 \\
\hline \multirow{3}{*}{\multicolumn{2}{|c|}{$\begin{array}{r}\text { TOTAL } 1956 \text { (ha) } \\
\text { OTAL CHANGE 2006-2015 (ha) }\end{array}$}} & 141,0 & 356,7 & 6765,1 & 6349,2 & 1870,9 & 3603,1 & 26,9 \\
\hline & & $-57,0$ & $-255,7$ & $-661,1$ & 289,1 & $-1636,0$ & 2324,5 & $-3,8$ \\
\hline & & Unveg & Anthropic & $\begin{array}{c}\text { Alp } \\
\text { grass_rocks }\end{array}$ & Shrubland & $\begin{array}{l}\text { Sparse } \\
\text { forest }\end{array}$ & $\begin{array}{l}\text { Dense } \\
\text { forest }\end{array}$ & $\begin{array}{c}\text { Riparian } \\
\text { veget }\end{array}$ \\
\hline \multirow{7}{*}{ ํํํ } & Unvegetated & 43,5 & 0,9 & 0,0 & 0,1 & 0,3 & 0,2 & 0,0 \\
\hline & Anthropic & 0,8 & 28,0 & 0,0 & 0,0 & 0,0 & 0,0 & 0,0 \\
\hline & Alpine grasslands and rocks & 1,7 & 0,0 & 90,0 & 0,1 & 0,3 & 0,0 & 0,0 \\
\hline & Shrubland & 2,2 & 38,4 & 6,9 & 94,9 & 0,3 & 0,0 & 0,0 \\
\hline & Sparse forest & 0,6 & 3,7 & 0,9 & 0,4 & 7,1 & 0,0 & 0,0 \\
\hline & Dense forest & 48,5 & 29,0 & 2,2 & 4,4 & 92,0 & 99,8 & 28,4 \\
\hline & Riparian vegetation & 2,7 & 0,0 & 0,0 & 0,0 & 0,0 & 0,0 & 71,6 \\
\hline
\end{tabular}


Transition matrices (Table 1) show that ruderal, unvegetated, and sparse forest classes suffered the highest retrogression, the extent of the reduction being higher in the PPZ than the OMPNP. Dense forests were the absolute winners, increasing considerably their extension in both reference areas at the expense of almost all the other land cover classes. The most noticeable change in the study site was the strong densification of sparse forests, and tree species that experimented higher increase were Pinus sylvestris in the mountain belt and Pinus uncinata in the upper part, as well as Fagus sylvatica, and Salix spp. by the rivers. Shrublands stayed relatively stable, but whereas their occupation slightly decreased in the protected area, it increased in the peripheral one. Alpine grasslands and rocky habitats slightly reduced their occupancy, again more in the unprotected than protected area.

The total edge of patches reduced in both areas between 1956 and 2015 (Table 2), mainly because the number of patches halved and their mean size doubled below the treeline. This means that some patches merged and ecotones decreased. The Shannon diversity index lowered in both reference areas, about $12 \%$ in the OMPNP and $16 \%$ in the PPZ (Table 2). Altogether, results indicate a homogenization driven by expansion, merging and densification of forest patches, including a slight shift upwards of the treeline at the cost of a very small surface of subalpine grasslands.

Table 2. Spatial metrics calculated for 2 reference areas (OMPNP: Ordesa and Monte Perdido National Park, PPZ: Peripheral Protection Zone), in two years (1956 and 2015), and above and below the current treeline (2100 $m$ a.s.l.). TE: total edge, NumP: number of patches, MPS: mean size of patches, SDI: Shannon diversity index.

\begin{tabular}{|lc|c|c|c|c|c|}
\hline & & Area (ha) & TE (km) & NumP & MPS & SDI \\
\hline OMPNP 1956 & & $\mathbf{1 5 6 9 2}$ & $\mathbf{1 6 2 7}$ & $\mathbf{3 3 4}$ & $\mathbf{4 7}$ & $\mathbf{1 , 2 5}$ \\
\hline & $<2100$ & 8416 & 1271 & 293 & 29 & 1,36 \\
\hline OMPNP 2015 & & $\mathbf{1 5 6 9 2}$ & $\mathbf{1 4 4 4}$ & $\mathbf{1 8 0}$ & $\mathbf{8 7}$ & $\mathbf{1 , 1}$ \\
\hline & $<2100$ & 8416 & 1070 & 142 & 59 & 1,14 \\
\hline & $\geq 2100$ & 7276 & 506 & 68 & 107 & 0,36 \\
\hline PPZ 1956 & $\mathbf{1 9 1 1 3}$ & $\mathbf{2 7 7 2}$ & $\mathbf{6 7 3}$ & $\mathbf{2 8}$ & $\mathbf{1 , 4 5}$ \\
\hline & $<2100$ & 11965 & 1987 & 607 & 20 & 1,48 \\
\hline & & 7149 & 1001 & 150 & 48 & 0,70 \\
\hline PPZ 2015 & $\mathbf{1 9 1 1 3}$ & $\mathbf{2 4 5 5}$ & $\mathbf{3 5 9}$ & $\mathbf{5 3}$ & $\mathbf{1 , 2 1}$ \\
\hline & $<2100$ & 11965 & 1647 & 293 & 41 & 1,12 \\
\hline & $\geq 2100$ & 7149 & 1001 & 140 & 51 & 0,71 \\
\hline
\end{tabular}




\subsection{Plant diversity response: winners and losers}

A preliminary list of 1338 plants resulted in the OMPNP (species level), although analyses were restricted to 1278 clearly differentiated taxa. The PPZ only adds 62 more taxa to the whole study site. Grasslands and rocky areas above the treeline constitute the land cover class with the highest plant number, and also the highest number of Pyrenean endemic plants (50 out of 52), although some of them occur over a wide altitudinal gradient (Fig. 4). A total of 23 threatened plants occur in the study area, 20 inside the limits of the OMPNP and 3 more outside in the peripheral zone (Fig. 4). Threatened plants are more widely distributed across land cover classes than endemics: 14 of them above the treeline, 8 associated to forests (sparse, dense or riparian, as well as forest gaps) and one to shrublands. As many as 31 out of our 70 target plants (some are both endemic and threatened) are intimately associated to highly imperturbable rocky habitats: screes, cliffs, erratic boulders, crests, or sparse rocky alpine grasslands. Altogether, these results indicate that most of the potentially vulnerable plants of the National Park are either on "winner" forests, totally or partly distributed in the stable habitats over the treeline, or can be considered rocky specialists.

\section{Discussion}

Our study on the landscape changes over the last 60 years in a highly valuable protected area of Central Pyrenees confirms an increase of the forest, and a reduction of landscape heterogeneity. Almost all changes of land cover occurred below the treeline (2100 $\mathrm{m}$ a.s.1.), and most of them in the currently low-populated peripheral area of the Ordesa and Monte Perdido National Park. In the PPZ, traditional uses (wood extraction, agriculture and grazing) were historically more intense than currently, and nowadays are higher than in the protected area. Forests increased both by densification and at the expense of open areas: mesic pastures, shrublands, and, to a much less extent, subalpine grasslands. Our results also show a strong stability of alpine systems, in line with previous observational and experimental studies carried out at much finer scales in the same area (Pardo, 2016).

The intensity of recorded changes in our study area was not as dramatic as in open Mediterranean regions (for example around $80 \%$ for a similar period in $\mathrm{S}$ France, Sirami et al., 2010), but more similar to other mountain areas (Améztegui et al., 2010; Tattoni et al., 2011). Previous analyses based on remote sensing over shorter temporal series (mid-1980s and mid-2000s period) concluded that changes in a wider area that included our study site took place below the potential tree line (96\% below $2100 \mathrm{~m}$ a.s.l.; Gartzia et al., 2014) and hardly affected the core of the OMPNP (Martinez-Vega et al., 2017). Interestingly, when comparing the 2006 and 2015 pictures we found very little changes, probably because forest expansion is close to reach the total suitable space. A deceleration in woodland expansion has also been found in two Italian watersheds with contrasted current management (Campagnaro et al., 2017), but the generalization of such deceleration in protected areas is unknown. 


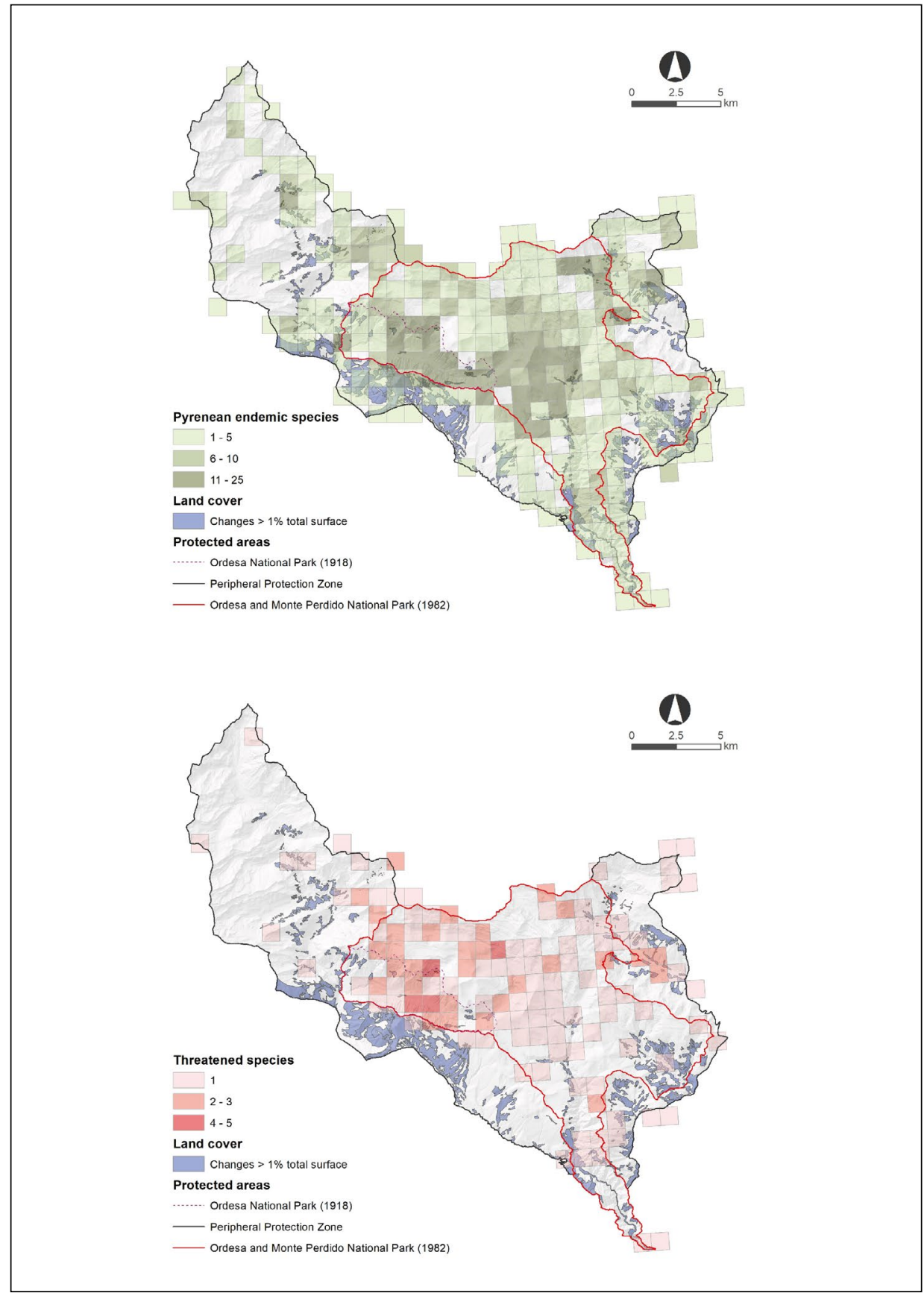

Figure 4. Distribution and abundance of Pyrenean endemic (above) and threatened (below) vascular plants in the Ordesa and Monte Perdido National Park (delimited by the red line) and Peripheral Protection Zone (surrounding area). 
Natural reforestation is a common pattern in other European mountains (MacDonald et al.,2000; Garbarino et al.,2014), and vegetation changes and woody plant encroachment in the study area are definitely related to the decline of traditional practices after rural depopulation starting in the 1930s (Améztegui et al., 2010; Garztia et al., 2014; Xystrakis et al., 2017). Livestock continues grazing in summer and autumn inside the OMPNP, but at low-intensity compared to historical times, which similarly to other mountains resulted in encroachment of shrubs and trees in the forest-alpine grassland ecotone. To what extent the observed changes are a consequence of warming or the decrease of grazing seems difficult to decipher given the lack of previous monitoring programs, the complexity of the topography, and habitat diversity (Batllori and Gutierrez, 2008). Upward treeline shifts and forest expansion are probably consequences of both climatic factors and decrease of human activities, although seems to be primarily controlled by land-use history (Álvarez-Martínez et al., 2014).

Landscape heterogeneity has decreased in our study area due to the prevalence of natural succession over human perturbations below the treeline, which is another frequent result when analyzing landscape dynamics (Sitzia et al., 2010; Campagnaro et al., 2017; but see opposite results in Garbarino et al., 2014). Densification and aggregation of forest patches reduced heterogeneity, which together with the stability of the alpine belt resulted in a reduction of ecotones. Moderate levels of perturbation (either natural like avalanches and wild board digging, or by human activity like cultivations) typically enhance diversity as a consequence of an increase of environmental heterogeneity (Roxburgh et al., 2004), and it should be considered for managers when a single kind of habitat takes over large areas as a result of natural succession. Habitat transformation is followed by the replacement of a myriad of macro- and microorganisms dependent on the ecological niches provided by structural elements such as trees, shrubs, rocks, or grasslands. Some organisms are dependent on elements only provided by very old stands in the case of forests though (Lindermayer and Laurance, 2017), and therefore their age should be considered besides extension for an effective management of the diversity they shelter.

Sirami et al. (2010) evaluated the impact of land-cover transformation of a mosaic landscape representative of the north-western Mediterranean Basin on several groups of organisms, by combining qualitative and quantitative data on populations trends. They found that, apart of amphibians and insects, rare or endemic species of birds, reptiles and plants were associated to open habitats and thus threatened by land abandonment. Our exploratory analysis with two groups of potentially vulnerable plants (Pyrenean endemics, and threatened) does not support the idea of a negative effect of recent landscape changes on them because they are located either in the most abundant and stable land-cover classes identified (alpine grasslands and rocky places) or inside the successful forests. Nevertheless, we used a coarse scale (land cover classes) that might hide important changes at finer scale, and there is not enough available information to make generalizations because results seem to be rather context-dependent. For example, an accelerated enhancement of richness has been reported on high European summits as a consequence of warming (Steinbauer et al., 2018), whereas increasing, neutral and decreasing trends of richness have been found after repeated sampling over time across European grasslands (Diekmann et al., 2014; Gillet et al., 2016). 
Concerning our study site, Pardo et al. (2015) found that grazing cessation did not have a strong effect on community structure except for an extremely warm and dry period, after comparing richness and abundance inside and outside livestock exclusions running for 20 years in subalpine grasslands. In the same line, Mariotte et al. (2013) found an unnoticeable but very valuable role of non-dominant plants contributing to the diversity of semi-natural grasslands of the Jura mountains, because their removal resulted in lower resistance of the community to climatic hazards. Traditional practices promoting diversity in grasslands, therefore, seem to be beneficial to buffer the effects of adverse climatic events.

The increase of forest occupancy clearly reduces plant diversity because of the lower number of plant species associated to forests compared to mesic pastures, but at this latitude it might also benefit understory herbs at the South limit of distribution. Almost two hundred plants are in this situation in the Pyrenees (García et al., in prep.), such as Cypripedium calceolus. After monitoring two Pyrenean populations of this threatened orchid over a decade, García et al. (2010) found that population trends were increasing despite severe herbivory in the one located in the PPZ, and the only plausible explanation was afforestation of populations of this iconic plant after comparing the 1956-2006 aerial pictures. The dramatic increase of the canopy where populations occur must have reduced considerably the temperature that plants experience despite overall warming in the region (EEA, 2017). Besides that, some of the forests of the OMPNP are very close to the absolute southern limit of distribution in the Pyrenees (Abies alba, Pinus uncinata) and others are keystone pieces of Habitats of Community Interests according to the European Habitats Directive (Fagus sylvatica). So, allowing forests to be shaped by natural processes after centuries of human disturbance, to preserve old stands of a minimum size must also be among the priorities of a protected space. A recent comprehensive review of forest fragmentation showed many detrimental shortand long-term effects on biodiversity (Haddad et al., 2015). Merging forest patches, therefore, should not be considered a concern from a biological point of view in a world where $70 \%$ of remaining forest is within $1 \mathrm{~km}$ of the forest's edge and subject to the degrading effects of fragmentation, and particularly when such process constitutes the natural succession of vegetation and does not affect the maintenance of natural alpine system on top of it. Nevertheless, many considerations have to be taken in mind, including the risk of fire, and the lost of diversity associated to the open places they transform.

The main losers of the lower human-pressure in the National Park are plants associated to cultivated fields (former crops and current mesic pastures), and other perturbed places. They have an important contribution to overall diversity of the area, but their presence and abundance beyond the Pyrenees make them less vulnerable than endemics or threatened. Our potential vulnerable plants are located either on "winner" or very stable habitats that will not disappear in the OMPNP even if the livestock disappeared. As part of an ongoing monitoring project of plant population and habitat dynamics in the National Park and Peripheral zone (see description of the method in García et al., 2018), we are tracking the local abundance of plant species occurring in more than 50 monitoring units, covering a 
wide spectrum of life forms, altitudes and habitats, many of them threatened or of Community interest according to the Habitats Directive. Preliminary results show an outstanding stability, with no plant extinction and very few declining populations even among the most endangered taxa (García et al., unpublished). These results do not support the forecasts produced by climatic models (for example Thuiller et al., 2005), and demonstrate the need of gathering more real information before alarming managers and policy-makers.

Like other mountain systems, the OMPNP should be viewed as a complex and heterogeneous system that is recovering from a much higher human pressure in the past. Such pressure is currently restricted to visitors footprint and a reduced stocking rate, which certainly exert a much lower effect compared to the period when the Pyrenees were heavily populated (maximum in the middle of the eighteen century, García-Ruiz et al., 2015). Early in the nineteen century the landscape showed signs of heavy land use, strong grazing, and forest overexploitation (Acín, 2000). In the recovering process there are inevitably local winners and losers among plants, animals and the hidden edaphic microbiota (see for example McKinney and Lockwood, 1999). Also changes in ecosystem services due to the reduction of soil erosion, increase of sequestering carbon from the atmosphere, or the settlement of watersheds. And some changes might have consequences far away, as for example on the hydrologic regimen downstream. Therefore shifts in natural systems should be interpreted from an integrative and longterm perspective, because of the interconnection of uncountable elements and processes.

\section{Conclusion}

In the Anthropocene period (Corlett, 2015), protected areas must play a key role for biodiversity preservation. They should become Noah's Arks not only for organisms, but also their environment and ecological relationships (Valiente-Banuet et al., 2015), become safer from the negative and "irreversibility" human pressure elsewhere. Managers have to take informed decisions on what land-owners, scientists, and the society consider important to preserve, in a world where agro-pastoral activities are decreasing in a probably irreversible way (García-Ruiz and Lasanta, 2018). By knowing how landscape changes restructures biodiversity at multiple spatial scales and biological organization levels, and the real possibilities of actively managing ecosystems with current resources, we will be able to make an effective, balanced and sustainable preservation of natural and cultural landscapes. In this study we demonstrated that landscape changes have been more intense in the peripheral zone in than the protected National Park, and hardly affected above the treeline. Also, that the reduction of traditional land uses are not jeopardizing threatened or narrow-distributed plants, and it might even improve the situation of some plants and trees at the South limit of distribution. But landscape diversity is getting lower in the National Park, and diversity reduction could be slowed down by promoting the presence of patches of open areas in the forest matrix. Contrary to what human societies did for their own survival in the far past, we have now the tools to regulate the intensity of disturbance in order to assure the long-term persistence of as many biodiversity elements as possible. 


\section{Acknowledgements}

E. Anie (Huesca Photo Library) provided Fig. 1, and R. Antor an interesting discussion on the subject after reading a manuscript draft. This study is a product of the DYNBIO project (OAPN, Ref 1656/2015).

\section{References}

Acín, J.L. 2000. Tras las huellas de Lucien de Briet. Bellezas del Alto Aragón. Prames, Zaragoza, 396 pp. ISBN 9788483210642.

Adamczyk, J., Tiede, D. 2017. ZonalMetrics - a Python toolbox for zonal landscape structure analysis. Computers \& Geosciences, 99, 91-99. http://doi.org/10.1016/j.cageo.2016.11.005.

Álvarez-Martínez, J.M., Suárez-Seoane, S., Stoorvogel, J.J., de Luis Calabuig, E. 2014. Influence of land use and climate on recent forest expansion: a case study in the EurosiberianMediterranean limit of north-west Spain. Journal of Ecology 102, 905-919. https://doi. org/10.1111/1365-2745.12257.

Améztegui, A., Brotons, L., Coll, L. 2010. Land-use changes as major drivers of mountain pine (Pinus uncinata Ram.) expansion in the Pyrenees. Global Ecology and Biogeography 19 (5), 632-641. https://doi.org/10.1111/j.1466-8238.2010.00550.x.

Anonym 1976. Capitulaciones y concordias sobre aprovechamiento ganadero de las praderas de Gorit. In: M. Daumas (Ed.), La vie rurale dans le Haut Aragon Oriental. C.S.I.C., Madrid, pp. 774.

Anonym 1995. Decreto 49/1995 de 28 de marzo, de la Diputación General de Aragón, por el que se regula el Catálogo de Especies Amenazadas de Aragón.

Anonym 2005. Decreto 181/2005, de 6 de septiembre, del Gobierno de Aragón, por el que se modifica parcialmente el Decreto 49/1995, de 28 de marzo, de la Diputación General de Aragón, por el que se regula el Catálogo de Especies Amenazadas de Aragón.

Anonym 2011. Real Decreto 139/2011, de 4 de febrero, para el desarrollo del Listado de Especies Silvestres en Régimen de Protección Especial y del Catálogo Español de Especies Amenazadas.

Bañares, A., Blanca, G., Güemes, J., Moreno, J.C., Ortiz, S. 2011. Atlas y Libro Rojo de la Flora Vascular Amenazada de España. Adenda 2010. Dirección General de Medio Natural y Política Forestal y Sociedad Española de Biología de la Conservación de Plantas. Madrid, 170 pp.

Batllori, E., Gutiérrez, E. 2008. Regional tree line dynamics in response to global change in the Pyrenees. Journal of Ecology 96, 1275-1288. https://doi.org/10.1111/j.13652745.2008.01429.x.

Bonari, G., Fajmon, K., Malenovský, I., Zelený, D., Holuša, J., Jongepierová, I., Kočárek, P., Konvička, O., Uřičář, J., Chytrý, M. 2017. Management of semi-natural grasslands benefiting both plant and insect diversity: The importance of heterogeneity and tradition. Agriculture, Ecosystems \& Environment 246, 243-252 https://doi.org/10.1016/j.agee.2017.06.010.

Campagnaro, T., Frate, L., Carranza, M.L., Sitzia, T. 2017. Multi-scale analysis of alpine landscapes with different intensities of abandonment reveals similar spatial pattern changes: Implications for habitat conservation. Ecological Indicators 74, 147-159. https://doi. org/10.1016/j.ecolind.2016.11.017.

CNIG 2018. Centro Nacional de Información Geográfica. Available at: http://centrodedescargas. cnig.es/CentroDescargas/index.jsp; download in March 2018.

Commission of the European Communities 1992. Council Directive 92/43/EEC of 21 May 1992 on the conservation of natural habitats and of wild fauna and flora.

Corlett, R.T. 2015. The Anthropocene concept in ecology and conservation. Trends in Ecology and Evolution 30, 36-41. https://doi.org/10.1016/j.tree.2014.10.007. 
Diekmann, M., Jandt, U., Alard, D., Bleeker, A., Corcket, E., Gowing, D.J.G., Stevens, C.J., Duprè, C. 2014. Long-term changes in calcareous grassland vegetation in North-western Germany - No decline in species richness, but a shift in species composition. Biological Conservation 172, 170-179. https://doi.org/10.1016/j.biocon.2014.02.038.

EEA (European Environment Agency), 2017. Climate change, impacts and vulnerability in Europe 2016. An indicator-based report. Available at: https://www.eea.europa.eu/publications/ climate-change-impacts-and-vulnerability-2016.

Engler, R., Randin, C.F., Thuiller, W., Dullinger, S., Zimmermann, N.E., Araújo, M.B., Pearman, P.B., Le Lay, G., Piedallu, C., Albert, C.H., Choler, P., Coldea, G., De Lamo, X., Dirnböck, T., Gégout, J.-C., Gómez-García, D., Grytnes, J.-A., Heegaard, E., Høistad, F., NoguésBravo, D., Normand, S., Puşcaş, M., Sebastià, M.-T., Stanisci, A., Theurillat, J.-P., Trivedi, M.R., Vittoz, P., Guisan, A. 2011. $21^{\text {st }}$ century climate change threatens mountain flora unequally across Europe. Global Change Biology 17, 2330-2341. https://doi.org/10.1111/ j.1365-2486.2010.02393.x.

Falcucci, A., Maiorano, L., Boitani, L. 2007. Changes in land-use/land-cover patterns in Italy and their implications for biodiversity conservation. Landscape Ecology 22, 617-631. https://doi. org/10.1007/s10980-006-9056-4.

Garbarino, M., Sibona, E., Lingua, E., Motta, R. 2014. Decline of traditional landscape in a protected area of the southwestern Alps: The fate of enclosed pasture patches in the land mosaic shift. Journal of Mountain Science 11, 544-554. https://doi.org/10.1007/s11629-013-2666-9.

García-Ruiz, J.M., López-Moreno, J.I., Lasanta, T., Vicente-Serrano, S.M., González-Sampériz, P., Valero-Garcés, B.L., Sanjuán, Y., Beguería, S., Nadal-Romero, E., Lana-Renault, N., Gómez-Villar, A. 2015. Los efectos geoecológicos del cambio global en el Pirineo Central español: una revisión a distintas escalas espaciales y temporales. Pirineos 170, e012. https:// doi.org/10.3989/Pirineos.2015.170005.

García-Ruiz, J.M., Lasanta, T. 2018. El Pirineo Aragonés como paisaje cultural. Pirineos 173, 038. https://doi.org/10.3989/pirineos.2018.173005.

García, M.B., Goñi, D., Guzmán, D. 2010. Living at the Edge: Local versus Positional Factors in the Long-Term Population Dynamics of an Endangered Orchid. Conservation Biology 24, 1219-1229. https://doi.org/10.1111/j.1523-1739.2010.01466.x.

García, M.B., Silva, J.L., Tejero, P., Pardo, I., Gómez, D. 2018. Tracking the long-term dynamics of plant diversity in Northeast Spain with a network of volunteers and rangers. Regional Environmental Change 18, 493. https://doi.org/10.1007/s10113-018-1350-6.

Gartzia, M., Alados, C.L., Pérez-Cabello, F. 2014. Assessment of the effects of biophysical and anthropogenic factors on woody plant encroachment in dense and sparse mountain grasslands based on remote sensing data. Progress in Physical Geography 38, 201-217. https://doi. org/10.1177/0309133314524429.

Gillet, F., Mauchamp, L., Badot, P.M., Mouly, A. 2016. Recent changes in mountain grasslands: a vegetation resampling study. Ecology and Evolution 6, 2333-2345. https://doi.org/10.1002/ ece3.1987.

Gómez, D., Lorda, M., Font, X., M.B. García (in press). Revisión de la flora endémica de los Pirineos Materiales preliminares para una lista roja pirenaica. Actas XI Coloquio Internacional de Botánica Pirenaico-Cantábrica. Bértiz, Navarra.

Haddad, N.M., Brudvig, L.A., Clobert, J., Davies, K.F., Gonzalez, A., Holt, R.D., Lovejoy, T.E., Sexton, J.O., Austin, M.P., Collins, A.D., Cook, W.M., Damschen, E.I., Ewers, R.M., Foster, B.L., Jenkins, C.N., King, A.J., Laurance, W.F., Levey, D.J., Margules, Ch. R., Melbourne, B.A., Nicholls, A.O., Orrock, J.L., Song, D.X., Townshend, J.R. 2015. Habitat fragmentation and its lasting impact on Earth's ecosystems. Science Advances 1 (2), e1500052. https://doi. org/10.1126/sciadv.1500052. 
Hudewenz, A., Klein, A.M., Scherber, C., Stanke, L., Tscharntke, T., Vogel, A., Weigelt, A., Weisser, W.W., Ebeling, A. 2012. Herbivore and pollinator responses to grassland management intensity along experimental changes in plant species richness. Biological Conservation 150, 42-52. https://doi.org/10.1016/j.biocon.2012.02.024.

Lindenmayer, D.B.,Laurance, W.F. 2017. The ecology, distribution, conservation and management of large old trees. Biological Reviews 92, 1434-1458. https://doi.org/10.1111/brv.12290.

López-Moreno, J.I., Goyette, S., Beniston, M. 2008. Climate change prediction over complex areas: spatial variability of uncertainties and predictions over the Pyrenees from a set of regional climate models. International Journal of Climatology 28, 1535-1550. https://doi. org/10.1002/joc. 1645 .

MacDonald, D., Crabtree, J.R., Wiesinger, G., Dax, T., Stamou, N., Fleury, P., Gutierrez Lazpita, J., Gibon, A. 2000. Agricultural abandonment in mountain areas of Europe: Environmental consequences and policy response. Journal of Environmental Management 59, 47-69. https:// doi.org/10.1006/jema.1999.0335.

McKinney, M., Lockwood, J. 1999. Biotic homogenization: a few winners replacing many losers in the next mass extinction. Trends in Ecology and Evolution 14 (11), 450-453. https://doi. org/10.1016/S0169-5347(99)01679-1.

Mantyka-Pringle, C.S., Martin, T.G., Rhodes, J.R. 2012. Interactions between climate and habitat loss effects on biodiversity: a systematic review and meta-analysis. Global Change Biology 18, 1239-1252. https://doi.org/10.1111/j.1365-2486.2011.02593.x.

Mariotte, P., Vandenberghe, C., Kardol, P., Hagedorn, F., Buttler, A. 2013. Subordinate plant species enhance community resistance against drought in semi-natural grasslands. Journal of Ecology 101, 763-773. https://doi.org/10.1111/1365-2745.12064.

Martínez-Vega, J., Díaz, A., Nava, J.M., Gallardo, M., Echavarría, P. 2017. Assessing Land UseCover Changes and Modelling Change Scenarios in Two Mountain Spanish National Parks. Environments 4 (4), 79. https://doi.org/10.3390/environments4040079.

Moreno, J.C., Coord. 2008. Lista Roja 2008 de la flora vascular española. Dirección General de Medio Natural y Política Forestal (Ministerio de Medio Ambiente y Medio Rural y Marino) y Sociedad Española de Biología de la Conservación de Plantas), Madrid, 86 pp.

Newbold, T., Hudson, L.N., Hill, S.L.L., Contu, S., Lysenko, I., Senior, R.A., Börger, L., Bennett, D.J., Choimes, A., Collen, B., Day, J., De Palma, A., Díaz, S., Echeverria-Londoño, S., Edgar, M.J., Feldman, A., Garon, M., Harrison, M.L.K., Alhusseini, T., Ingram, D.J., Itescu, Y., Kattge, J., Kemp, V., Kirkpatrick, L., Kleyer, M., Correia, D.L.P., Martin, C.D., Meiri, S., Novosolov, M., Pan, Y., Phillips, H.R.P., PURVES, D.W., Robinson, A., Simpson, J., Tuck, S.L., Weiher, E., White, H.J., Ewers, R.M., Mace, G.M., Scharlemann, J.P.W., Purvis, A. 2015. Global effects of land use on local terrestrial biodiversity. Nature 520, 45-50. https://doi.org/10.1038/nature14324.

Pardo, I. 2016. Distribution and dynamics of multiple components of plant diversity in a high mountain area: the Ordesa-Monte Perdido National Park. Doctoral Dissertation. Barcelona University. Available at: http://hdl.handle.net/2445/99183.

Pardo, I., Doak, D.F., García-González, R., Gómez, D., García, M.B. 2015. Long-term response of plant communities to herbivore exclusion at high elevation grasslands. Biodiversity and Conservation 24, 3033-3047. https://doi.org/10.1007/s10531-015-0996-3.

Rempel, R.S., Kaukinen. D., Carr, A.P. 2012. Patch Analyst and Patch Grid. Ontario Ministry of Natural Resources. Centre for Northern Forest Ecosystem Research, Thunder Bay, Ontario. Available at: http://www.scirp.org/(S(lz5mqp453edsnp55rrgjct55))/reference/ ReferencesPapers.aspx?ReferenceID=2031666.

Roxburgh, S.H., Shea, K., Wilson, J.B. 2004. The intermediate disturbance hypothesis: patch dynamics and mechanisms of species coexistence. Ecology 85, 359-371. https://doi. org/10.1890/03-0266. 
Sala, O.E., Chapin, F.S., Armesto, J.J., Berlow, E., Bloomfield, J., Dirzo, R., Huber-Sanwald, E., Huenneke, L.F., Jackson, R.B., Kinzig, A., Leemans, R., Lodge, D.M., Mooney, H.A., Oesterheld, M., Poff, N.L., Sykes, M.T., Walker, B.H., Walker, M., Wall, D.H. 2000. Global biodiversity scenarios for the year 2100. Science 287 (5459), 1770-1774. https://doi. org/10.1126/science.287.5459.1770.

Scheffers, B.R., De Meester, L., Bridge, T.C.L., Hoffmann, A.A., Pandolfi, J.M., Corlett, R.T., Butchart, S.H.M., Pearce-Kelly, P., Kovacs, K.M., Dudgeon, D., Pacifici, M., Rondinini, C., Foden, W.B., Martin, T.G., Mora, C., Bickford, D., Watson, J.E.M. 2016. The broad footprint of climate change from genes to biomes to people. Science 354 (6313), aaf7671. https://doi.org/10.1126/science.aaf7671.

Sirami, C., Nespoulous, A., Cheylan, J.-P., Marty, P., Hvenegaard, G.T., Geniez, P., Schatz, B., Martin, J.L. 2010. Long-term anthropogenic and ecological dynamics of a Mediterranean landscape: Impacts on multiple taxa. Landscape and Urban Planning 96, 214-223. https:// doi.org/10.1016/j.landurbplan.2010.03.007.

Sitzia, T., Semenzato, P., Trentanovi, G. 2010. Natural reforestation is changing spatial patterns of rural mountain and hill landscapes: A global overview. Forest Ecology and Management 259 (8), 1354-1362. https://doi.org/10.1016/j.foreco.2010.01.048.

Steinbauer, M.J., Grytnes, J.A., Jurasinski, G., Kulonen, A., Lenoir, J.,Pauli,H., Rixen, C., Winkler, M., Bardy-Durchhalter, M., Barni, E., Bjorkman, A.D., Breiner, F.T., Burg, S., Czortek, P., Dawes, M.A., Delimat, A., Dullinger, S., Erschbamer, B., Felde, V.A., Fernández-Arberas, O., Fossheim, K.F., Gómez-García, D., Georges, D., Grindrud, E.T., Haider, S., Haugum, S.V., Henriksen, H., Herreros, M.J., Jaroszewicz, B., Jaroszynska, F., Kanka, R., Kapfer, J., Klanderud, K., Kühn, I., Lamprecht, A., Matteodo, M., di Cella, U.M., Normand, S., Odland, A., Olsen, S.L., Palacio, S., Petey, M., Piscová, V., Sedlakova, B., Steinbauer, K., Stöckli, V., Svenning, J.C., Teppa, G., Theurillat, J.P., Vittoz, P., Woodin, S.J., Zimmermann, N.E., Wipf, S. 2018. Accelerated increase in plant species richness on mountain summits is linked to warming. Nature 556 (7700), 231-234. https://doi.org/10.1038/s41586-018-0005-6.

Tattoni, C., Ciolli, M., Ferretti, F. 2011. The Fate of Priority Areas for Conservation in Protected Areas: A Fine-Scale Markov Chain Approach. Environmental Management 47, 263-278. https://doi.org/10.1007/s00267-010-9601-4.

Thuiller, W., Lavorel, S., Araújo, M., Sykes, M., Prentice, I. 2005. Climate change threats to plant diversity in Europe. In: H.A. Mooney (Ed.), Proceedings of the National Academy of Sciences of the United States of America 102 (23), 8245-8250. https://doi.org/10.1073/ pnas.0409902102.

Valiente-Banuet, A., Aizen, M.A., Alcántara, J.M., Arroyo, J., Cocucci, A., Galetti, M., García, M.B., García, D., Gómez, J.M., Jordano, P., Medel, R., Navarro, L., Obeso, J.R., Oviedo, R., Ramírez, N., Rey, P.J., Traveset, A., Verdú, M., Zamora, R. 2015. Beyond species loss: The extinction of ecological interactions in a changing world. Functional Ecology 29, 299-307. https://doi.org/10.1111/1365-2435.12356.

Wielgolaski, F.E., Hofgaard, A., Holtmeier, F.K. 2017. Sensitivity to environmental change of the treeline ecotone and its associated biodiversity in European mountains. Climate Research 73, 151-166. https://doi.org/10.3354/cr01474.

Wilson, J.B., Peet, R.K., Dengler, J., Pärtel, M. 2012. Plant species richness: the world records. Journal of Vegetation Science 23,796-802.https://doi.org/10.1111/j.1654-1103.2012.01400.x.

Xystrakis, F., Psarras, T., Koutsias, N. 2017. A process-based land use/land cover change assessment on a mountainous area of Greece during 1945-2009: Signs of socio-economic drivers. Science of the Total Environment 587-588, 360-370. https://doi.org/10.1016/j. scitotenv.2017.02.161. 